\title{
EVALUATION OF THE PERFORMANCE FOR THE WASTEWATER TREATMENT PLANT THROUGH MEASURING PHYSICAL AND CHEMICAL PARAMETERS
}

* EMARA M.M*, EL-SABBAGH I.A.A*, AWAD F.K ${ }^{* *}$ AND HUSSEIN N.M*

*Chemistry Department, Faculty of Science, Al-AZhar University, Egypt scdreh@yahoo.commail:

** Chemistry Department, Faculty of Education, Suez Canal University, Egypt E-mail:awadpoll@yahoo.com

\begin{abstract}
Domestic sewage treatment plant at Suez consists of both primary treatment ponds(mechanical step)where the large particles was removed and secondary treatment ponds .The water samples were collected from different stages of domestic sewage treatment plant during the period from March 2003 to February 2004,from locations influent sewage water(A),aerated lagoon(B),facultative lagoon(C) and effluent water( D). The data obtained indicates that, the suspended solids (SS) values decrease as going from location A(influent) to location D(effluent) during almost all seasons. This finding shows that the effluent of domestic sewage after passing through primary treatment stage it has been clarified. Seasonal variation of dissolved oxygen contents are fluctuated between the lowest values of $0.74 \mathrm{mg} / \mathrm{L}$ at location A in autumn 2003and the highest value of $5.48 \mathrm{mg} / \mathrm{L}$ at location D in winter 2004. On contrary, the minimum biological oxygen demand (BOD) value was $150 \mathrm{mg} / \mathrm{L}$ recorded at location D in winter 2004, while the maximum value was $979 \mathrm{mg} / \mathrm{L}$ at location A in Autumn 2003. The chemical oxygen demand(COD)contents at the domestic sewage treatment plant are in harmony with the biological oxygen demand (BOD)values as indicated from a high significant correlation coefficient $(r=0.979, P \leq 0.05)$ between them. Furthermore, secondary treatment will reduce effluent BOD, COD and pathogen contents. Removal percents of sulphide ion from location $\mathrm{A}$ to location $\mathrm{D}$ at domestic sewage treatment plant were 30\%,9.07\%,6.06\% and 6.52\% recorded during Spring2003,Summer2003,Autumn2003 and Winter 2004, respectively. Similarly, removal percents of ammonia concentrations are varied from a higher value of $36.36 \%$ recorded during spring 2003 to a lower of $3.53 \%$ recorded in autumn 2003. On the other hand, the maximum concentration of reactive phosphate in the domestic sewage was $4.61 \mathrm{mg} / \mathrm{L}$ recorded at location A in Autumn 2003as the result of use the detergents in house.
\end{abstract}

\section{Introduction}

There are few reliable figures on the share of the wastewater collected in sewers that is being treated in the world. In many developing countries the bulk of domestic and industrial wastewater is discharged without any treatment or after primary treatment only. In Latin America about 15\% of collected wastewater passes through treatment plants (with varying levels of actual treatment). In Venezuela, a below 
average country in South America with respect to wastewater treatment, 97 percent of the country's sewage is discharged raw sewage into the environment[1]. Even a highly industrialized country such as the People's Republic of China discharges about 55 percent of all sewage without treatment of any type [2]. In a relatively developed Middle Eastern country such as Iran, Tehran's majority of population has totally untreated sewage injected to the city's groundwater [3]. Most of sub-Saharan Africa is without wastewater treatment. Effective sewage treatment prevents a variety of ailments that can be spread by exposure to pathogens that can be present in untreated sewages, and thus helps prevent disease. Discharges of untreated sewage can contaminate ground waters and surface waters used for drinking, recreation, fish and shellfish fisheries.

Untreated sewage from failed conventional septic systems or sewage discharged directly into the environment can percolate into groundwater, contaminating drinking-water wells with pathogens. The discharge of untreated sewage to streams can spread disease through direct contact, making such streams unfit for forms of recreation that involve skin contact with the water such as swimming and boating. Disease can also spread by indirect (secondary) contact such as through contact with rodents or insects that received primary exposure and in turn harbor the pathogens. Discharged, untreated sewage also can damage the receiving streams' ability to support healthy, living communities of aquatic organisms and can contaminate fisheries. The dumping of domestic sewage into the environment represents the international and local problem. Where the disposal sewage may be carried away by the current to the other places, but never disappears. The term pure, where used in a water pollution context, will mean a state of water in which no substance is present in sufficient concentration to prevent the water from being used for normal purpose. The effect of primary sedimentation as mean for domestic sewage treatment is investigated based on the removal of organic load and suspended solids sewage effluents. The variation of nutrient salts concentrations in the coastal water of the Red sea was studied ${ }^{(4)}$.The results indicated that the high regional average values of nitrate, phosphate and silicate at locations in the vicinity of waste outfalls coincided with the direct additions of large loads of these nutrients from sewage effluents. Also, the water quality of Abu Qir Bay in Alexandria was investigated during 19992000.The obtained results revealed that high levels of different inorganic nitrogen as the result that of discharge the sewage and agricultural effluents[5].Study the effect 
of contamination of El-max Bay water, Egypt with different kinds of sewage, agricultural and industrial wastes showed that the increase in the salinity values in the bay water was correlated with the discharge of the sewage water directly to the bay water [6].The changes in physico-chemical characteristics of the Augera stream water (Spain)was studied[7]. The data indicated that the eutrophication problems are the most aspects appeared under the effect of domestic sewage from human settlement. In the same context, the nutrient modeling from the source to the river load was studied and revealed that, high levels of nitrate and phosphate cause eutrophication in fresh water and coastal water [8].In an anaerobic digestion of sludge and industrial wastes, hydrogen sulphide is evolved along with methane and carbon dioxide [9].The removal of silica and other contaminants (hardness and trace metals) from raw water have been removed up to 67-96 \%by soda lime in presence of a poly electrolyte. A sampling campaign was conducted in order to characterize the quality and quantity of individual domestic grey water stream. Domestic grey water was found to contribute as much as $55-70 \%$ of the specific daily load of total suspended solids and biological oxygen demand in municipal sewage [6]. The objective of this study was to evaluate the performance of the domestic sewage treatment Plant at Suez region through monitoring the physic-chemical parameters of the sewage before and after treatment which include:pH,conductivity,total solids(TDS),suspended solids(SS), turbidity ,dissolved oxygen(DO),chemical oxygen demand (COD)Biological oxygen demand (BOD), ammonia, phosphate, total phosphate, chloride and sulphide ion. In addition to, development of basis long term pollution monitoring plan for the study area with emphasis the accumulation of pollutants.

\section{Materials and method}

\section{Description of the area of investigation:}

Domestic sewage treatment plant at Suez located between longitude $32^{\circ} 47^{`} \mathrm{E}$ and latitude $29^{0}{ }^{95} \mathrm{~N}$. Domestic sewage consist of discharges of dirty water from bathrooms, lavatories and kitchens, where the amount of drainage water [7] from the plant was $130 \times 10^{3} \mathrm{~m}^{3} /$ day. Domestic sewage is a complex mixture of minerals and organic matter in many forms, including large and small particles of solid matter, substances in solution, in suspension and colloidal dispersion. The domestic sewage treatment plant consists of primary treatment ponds (mechanical step) where the large particles were removed by allowing the sewage to flow across screens and slowly along lagoon. Sludge of insoluble particles forms are settled at the bottom of 
the lagoon, while liquid grease which is lighter than water layer was skimmed off by skimmer. After passing the wastewater through conventional primary treatment stage it was transferred to the secondary treatment stage (biological treatment) where most of organic matter was oxidized by microorganisms to carbon dioxide and water. The system was kept well aerated to speed the oxidation process.Furthermore, nitrification process was occurred where the organic nitrogen compounds were converted to nitrate ion and carbon dioxide [8] .Finally, and the wastewater was discharged into the Suez bay through El-kabanon drain south of Suez city.

\section{Sampling:}

The water samples were collected from different stages of domestic sewage treatment plant during the period from March 2003 to February 2004.Where subsurface water samples of the drainages at domestic sewage treatment plant from locations influent sewage water(A),aerated lagoon(B),Facultative lagoon(C) and effluent water( D). The time of sampling and the depths of treatment ponds were collected in table 1.

\section{Analytical methods}

The total suspended solid was determined by pouring 50 mLof well mixed sample into a weighed evaporating dish. Then was evaporated in oven at $180 \mathrm{C}^{\circ}$ and the dish was dried to constant weight. Then the dish was cooled in desiccator. The difference in weight of the evaporating dish after and before drying was recorded [10]. Miltimeter instrument; WTW (Wissenshaftlich Technische Workstation, GMBH-Germany) was used for measuring the following parameters: $\mathrm{pH}$, conductivity, chloride ion, total dissolved solids, and turbidity. Sulphide ion in wastewater sample was preserved using four drops of $2 \mathrm{~N}$ zinc acetate solution and sodium hydroxide for $100 \mathrm{~mL}$ sample .Then the precipitate of zinc sulphide $(\mathrm{ZnS})$ was dissolved with5mL of $6 \mathrm{~N}$ hydrochloric acid $(\mathrm{HCl})$ and exactly known volume of iodine solution was added. The excess of iodine was titrated with standard sodium thiosulphate solution and starch as indicator[10] .On the other hand ,the dissolved oxygen was carried out in wastewater samples using Winkler method[10].While biological oxygen demand was determined as the following: the dissolved oxygen concentration was measured immediately after collection of sample in bottle as blank while, the other wastewater sample in bottle was incubated at $20^{\circ} \mathrm{C}$ for five 
days .At the end of five days period the bottle was removed from the incubator and the residual dissolved oxygen was determined using Winkler method as mentioned previous. Where the biological oxygen demand was calculated by the following: BOD $(\mathrm{mg} / \mathrm{L})=(\mathrm{A}-\mathrm{B}) \mathrm{N} / \mathrm{V}$ Where; $\mathrm{A}=$ =volume of thiosulphate equivalent to initial dissolved oxygen concentration, $\mathrm{B}=$ volume of thiosulphate equivalent to dissolved oxygen after five days incubation period, $\mathrm{N}=$ normality of sodium thiosulphate solution $\mathrm{V}=$ sample volume $\mathrm{mL}$. The chemical oxygen demand(COD)was determined by refluxing wastewater sample with oxidizing agent potassium dichromate for two hours in acidic medium and presence of sliver sulphate as catalyst.Also,mercury sulphate was added to eliminate the interference of chloride ions. The sample was cooled and titrated against a standard ferrous ammonium sulphate (FAS) solution and ferrion indicator. Where the chemical oxygen demand was calculated from the following: COD mg= (A-B)N/V

Where; $A=m L$ of FAS required for titration blank,$B=m L$ of FAS required for titration of sample, $\mathrm{N}=$ normality of standard ferrous ammonium sulphate solution, $\mathrm{V}=$ sample volume $\mathrm{mL}$. Orthophosphate was detected by adding ammonium molybdate solution and reduced molybdophsophoric acid which was formed by stannous chloride solution. Then the absorbance of the blue color formed was measured at wave length 690nm using spectrophotometer(Metirtek SP830).Ammonia was detected using Nessler method where the absorbance of yellow brown color was measured at wave length $450 \mathrm{~nm}$ using spectrophotometer (Metirtek SP-830).

\section{Results and discussion}

The physical and chemical data in different stages of domestic sewage treatment plant are listed in table 2.From the results it was observed that, the higher total dissolved solids(TDS) value of 3304mg/l and lower one of $2331 \mathrm{mg} / \mathrm{L}$ were recorded in winter2004 and summer 2003,repectively at location D(effluent).In general, the recorded values of TDS in different stages of domestic sewage treatment plant are exceeded the permissible limit(2000mg/L)according to the Egyptian environmental law 4/1994.Look at table 2 it can be observed that, the suspended solids(SS)values decrease as going from location A(influent) to location $\mathrm{D}$ (effluent) in almost all seasons. This finding shows that the effluent of domestic sewage after passing through primary treatment stage it has been clarified. Also in the mechanical treatment, the influx (influent) of sewage water is strained to remove all large 
objects that are deposited in the sewer system, such as rags, sticks, condoms, sanitary towels (sanitary napkins) or tampons, cans, fruit, etc. This is most commonly done with a manual or automated mechanically raked screen. This type of waste is removed because it can damage or clog the equipment in the sewage treatment plant. In the same context, tubidity is caused principally by the presence of colloidal matter and suspended solids. Table 1 shows that the turbidity readings are fluctuated between the maximum value of 197NTU and minimum value of 9.5NTU were scored at locations A and D during Winter 2004 and Autumn 2003 respectively. The suspended solids values are in harmony with turbidity readings as indicated from a significant positive correlation $(\mathrm{r}=0.66, \mathrm{p} \leq 0.05)$ between them. The electrical conductivity (EC) is considered the main parameter for studying the characteristic of ecosystem as the result the presence of ions in the medium. The minimum EC value of $3330 \mu \mathrm{s} / \mathrm{cm}$ was recorded at location D in summer 2003and the maximum EC value of $4600 \mu \mathrm{s} / \mathrm{cm}$ was measured at location A in Winter 2004. This is mainly attributed to the influent waste sewage(location A) contains a high amount of dissolved solids. Furthermore, the sludge of insoluble particles are settled at the bottom of the primary treatment ponds which leads to the decrease in EC value at location D. Seasonal variation of dissolved oxygen contents are fluctuated between the lowest value of $0.74 \mathrm{mg} / \mathrm{L}$ at location A in Autumn 2003and the highest value of $5.48 \mathrm{mg} / \mathrm{L}$ at location D in Winter 2004 as shown in table 2.Such increase in dissolved oxygen content in Winter 2004 is mainly attributed to the solubility of atmospheric oxygen in winter increases where the solubility of oxygen gas in surface water depends on temperature ,pressure and salt contents[11].On contrary, the minimum biological oxygen demand (BOD) value was $150 \mathrm{mg} / \mathrm{L}$ recorded at location D in Winter 2004, while the maximum value was $979 \mathrm{mg} / \mathrm{L}$ at location A in Autumn 2003 as indicated in table 2.Furthermore, the chemical oxygen demand(COD) contents at the domestic sewage treatment plant are showed the similar trend of variation of biological oxygen demand, where the high value of $1204 \mathrm{mgO} / \mathrm{L}$ and the low value of $230.0 \mathrm{mgO} / \mathrm{L}$ were recorded at locations A and D during Autumn 2003 and Winter 2004 respectively as shown in table 2.These high values of BOD and COD reported at location A of the domestic sewage treatment plant is due to the high organic matter content in the raw domestic sewage which leads to the great consumption of dissolved oxygen. Generally, the oxidation of organic carbon, nitrogen and sulphur compounds in water [12] occurs as the 
following:

$$
\mathrm{C}_{\mathrm{n}} \mathrm{H}_{\mathrm{m}} \mathrm{O}_{\mathrm{e}} \mathrm{X}_{\mathrm{k}} \mathrm{N}_{\mathrm{j}} \mathrm{S}_{\mathrm{i}} \mathrm{P}_{\mathrm{h}}+\mathrm{bO}_{2} \rightarrow \mathrm{kHx}+\mathrm{jNH}_{3}+\mathrm{nCO}_{2}+\mathrm{iH}_{2} \mathrm{SO}_{4}+\mathrm{hH}_{3} \mathrm{PO}_{4}+\mathrm{yH}_{2} \mathrm{O}
$$

Where $\mathrm{x}$ represents the sum of all halogens in water and $\mathrm{b}$ represents the amount of oxygen required to oxidize organic compound to end products such as $\mathrm{CO}_{2}, \mathrm{NH}_{3}, \mathrm{H}_{2} \mathrm{PO}_{4}^{-}, \mathrm{SO}_{4}-$ and $\mathrm{b}$ can be calculated from

$$
\mathrm{b}=\mathrm{n}+\mathrm{m}-\mathrm{k}-3 \mathrm{j}-2 \mathrm{i}-3 \mathrm{~h} / 2
$$

The chemical oxygen demand(COD)contents at the domestic sewage treatment plant are in harmony with the biological oxygen demand (BOD)values as indicated from a high significant correlation coefficient( $\mathrm{r}=0.979, \mathrm{P} \leq 0.05)$ between them. Secondary treatment will reduce effluent BOD, COD and pathogen contents. Also, secondary treatment produces an effluent which must be both carefully handled and disposed of, usually through dispersal into the environment. Where the bacteria in the environment will consume organic contaminants, although this will reduce the levels of oxygen in the water and may significantly increase COD and BOD contents which leads to change in the overall ecology of the receiving water. The concentrations of sulphide ion at domestic sewage treatment plant are collected in table 2.Removal percents of sulphide ion from location A to location D at domestic sewage treatment plant were 30\%,9.07\%,6.06\% and 6.52\% recorded during spring2003,summer2003,autumn2003 and winter 2004, respectively. Similarly, removal percents of ammonia concentrations are varied from a higher value of 36.36\% recorded during Spring 2003 to a lower of 3.53\% recorded in Autumn 2003.The drop in the concentration of sulphide ion is maybe due to oxidation of sulphide ion and ammonia to sulphate and nitrate respectively, which reflects the of good performance of sewage treatment plant. Furthermore, ammonia nitrogen exists in aqueous solution as either ammonium ion $\left(\mathrm{NH}_{4}\right)^{+}$or ammonia $\mathrm{NH}_{3}$ depending in the $\mathrm{pH}$ reading of aqueous solution, where at $\mathrm{pH}$ reading lower than 8.5 the dominant form is ammonium ion. The $\mathrm{pH}$ range of domestic sewage before and after treatment was 7.16-7.94 which supported the previous interpretation for ammonia nitrogen. On the other hand, the maximum concentration of reactive phosphate in the domestic sewage was $4.61 \mathrm{mg} / \mathrm{L}$ recorded at location A in Autumn 2003as the result of use the detergents in house[13]. This concentration is reduced to $1.30 \mathrm{mg} / \mathrm{L}$ after treatment at domestic sewage treatment plant at Suez as shown in figure 1 .On the same context, total phosphate considers the second form of phosphorous that includes dissolved and particulate organic phosphorous. The increase in the concentration of total phosphate $(7.06 \mathrm{mg} / \mathrm{L})$ in the inlet sewage during summer 2003 may be due to the release of organic phosphate from bottom sludge in the 
treatment ponds to water. Then the concentration of total phosphate decreases to the lower value of $3.15 \mathrm{mg} / \mathrm{L}$ in the effluents of domestic sewage plant as indicated in figure 2.Human excreta, particularly urine, contain appreciable quantities of chlorides because some of the salt contained in food and water is excreted in the body wastes ${ }^{(14)}$.Furthermore, the human body discharges sodium chloride in the range from 8 grams to 15 grams /day. Also chloride ion is concerned in osmotic pressure regulation in the human body. The chloride concentrations are varied from a high range of 989.2-1121 mg/L and a low range 658-726 mg/L during winter 2004 and summer 2003 respectively, at domestic sewage treatment plant. Such increase in the chloride ion concentration in winter season may be attributed to the drought period in January and decaying of most organisms.

\section{Conclusion}

Wastewater may contain high levels of the nutrients nitrogen and phosphorus. Excessive release to the environment can lead to a build up of nutrients, called eutrophication, which can in turn encourage the overgrowth of weeds, algae, and cyano bacteria (blue-green algae). This may cause an algal bloom, a rapid growth in the population of algae. The algae numbers are unsustainable and eventually most of them die. The decomposition of the algae by bacteria uses up so much of oxygen in the water that most or all of the animals die, which creates more organic matter for the bacteria to decompose. In addition to causing deoxygenating, some algal species produce toxins that contaminate drinking water supplies. Advanced treatment is required if effluent is to be dispersed into surface water systems. A common standard is $30 \mathrm{mg} / \mathrm{L} \mathrm{BOD}$ and $30 \mathrm{mg} / \mathrm{L}$ suspended solids ("30/30"). In sensitive watersheds, a $10 \mathrm{mg} / \mathrm{L}$ BOD and $10 \mathrm{mg} / \mathrm{L}$ suspended solids ("10/10") standard is generally required. In some watersheds, regulations also impose nitrogen and phosphorus concentration limits. In these situations, wastewater treatment processes in addition to primary and secondary treatments are often required. Such processes are commonly termed as advanced treatment or tertiary treatment. The three disinfection mechanisms have several characteristics in common. All require ongoing maintenance, such as cleaning critical components. The two chemical systems (chlorination and ozonation) also require reagent purchase and storage, while ultraviolet (UV) light disinfection requires periodic bulb replacement. Ozonation, UV treatment, and some chlorination systems require electric power. All 
three disinfection systems are most effective when the effluent being treated has been thoroughly renovated before disinfection, as the presence of significant organic or particulate residue will interfere with the treatment process.
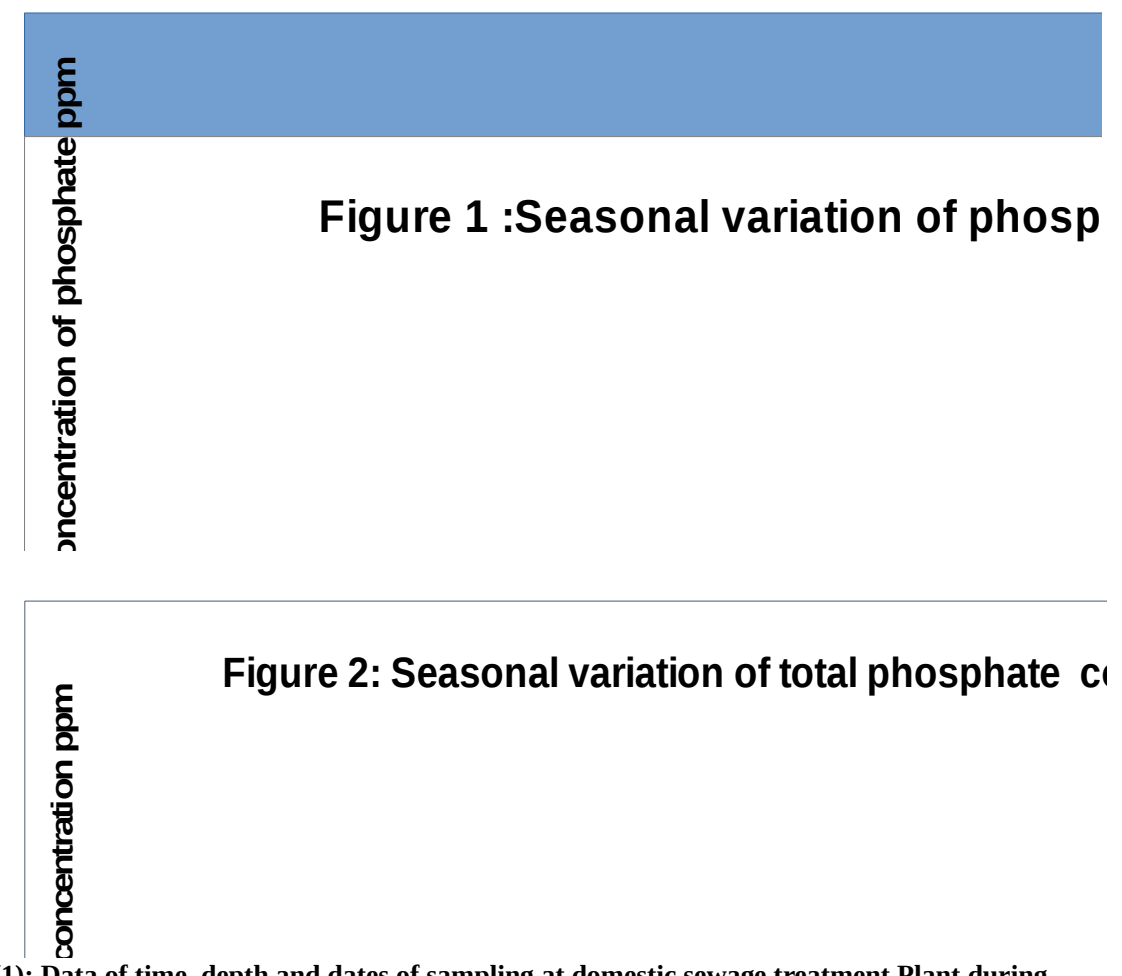

Table (1): Data of time, depth and dates of sampling at domestic sewage treatment Plant during 2003-2004.

\begin{tabular}{|l|c|c|c|c|c|c|c|c|}
\hline \multicolumn{1}{|c|}{ Date } & $\begin{array}{c}/ 26 / 3 \\
2003\end{array}$ & & $\begin{array}{c}/ 14 / 2 \\
2004\end{array}$ & & $\begin{array}{c}/ 9 / 10 \\
2003\end{array}$ & & $\begin{array}{c}/ 31 / 7 \\
2003\end{array}$ & \\
\hline Sampling locations & Hr:min & $\begin{array}{c}\text { Depth } \\
\mathrm{m}\end{array}$ & $\begin{array}{c}\text { Time } \\
\text { Hr:min }\end{array}$ & $\begin{array}{c}\text { Depth } \\
\mathrm{m}\end{array}$ & $\begin{array}{c}\text { Time } \\
\text { Hr:min }\end{array}$ & $\begin{array}{c}\text { Depth } \\
\mathrm{m}\end{array}$ & $\begin{array}{c}\text { Time } \\
\text { Hr:min }\end{array}$ & $\begin{array}{c}\text { Depth } \\
\mathrm{m}\end{array}$ \\
\hline Influent (A) & $13: 20$ & 3.0 & $17: 20$ & 3.0 & $12: 30$ & 3.0 & $12: 30$ & 3.0 \\
\hline Aerated lagoon (B) & $13: 40$ & 1.4 & 17.45 & 1.4 & $13: 05$ & 1.4 & $12: 55$ & 1.4 \\
\hline Facultative lagoon (C) & $12: 55$ & 1.3 & $18: 00$ & 1.3 & $\begin{array}{c}13: 15 \\
3\end{array}$ & 1.3 & $\begin{array}{c}13: 25 \\
5\end{array}$ & 1.3 \\
\hline Effluents (D) & $13: 15$ & 1.0 & $18: 20$ & 1.0 & $13: 23$ & 1.0 & $13: 40$ & 1.0 \\
\hline
\end{tabular}


4

Table 2: Seasonal variations of some physical and chemical parameters at Domestic sewage treatment plant during 2003-2004

\begin{tabular}{|c|c|c|c|c|c|c|c|}
\hline Parameter/ locations & season & $\mathrm{A}$ & $\mathrm{B}$ & $\mathrm{C}$ & $\mathrm{D}$ & & \\
\hline \multirow[t]{4}{*}{$\mathrm{pH}$} & Spring & 7.34 & 7.41 & 7.51 & 7.94 & & \\
\hline & Summer & 7.28 & 7.41 & 7.32 & 7.57 & & \\
\hline & Autumn & 7.16 & 7.82 & 7.6 & 7.5 & & \\
\hline & Winter & 7.55 & 7.51 & 7.6 & 7.8 & & \\
\hline \multirow[t]{4}{*}{$\mathrm{EC} \mu \mathrm{s} / \mathrm{cm}$} & Spring & 3660 & 3500 & 3470 & 3430 & & \\
\hline & Summer & 3670 & 3400 & 3350 & 3330 & & \\
\hline & Autumn & 3760 & 3620 & 3600 & 3480 & & \\
\hline & Winter & 4600 & 4490 & 4460 & 4420 & & \\
\hline \multirow[t]{4}{*}{ TDS mg/L } & Spring & 2560 & 2460 & 2430 & 240.1 & & \\
\hline & Summer & 2569 & 2380 & 2345 & 2331 & & \\
\hline & Autumn & 2632 & 2534 & 2520 & 2436 & & \\
\hline & Winter & 3255 & 3143 & 3122 & 3104 & & \\
\hline \multirow[t]{4}{*}{ S.S mg/L } & Spring & 241 & 250 & 200 & 49.5 & & \\
\hline & Summer & 637.3 & 273 & 177 & 94 & & \\
\hline & Autumn & 156.2 & 158 & 133 & 45 & & \\
\hline & Winter & 468 & 455 & 222 & 291 & & \\
\hline \multirow[t]{4}{*}{$\mathrm{DO} \mathrm{mg} / \mathrm{L}$} & Spring & 1.3 & 3 & 3.2 & 4.5 & & \\
\hline & Summer & 1.84 & 2.79 & 3.14 & 3.3 & & \\
\hline & Autumn & 0.74 & 3.35 & 3.55 & 4.12 & & \\
\hline & Winter & 0.95 & 1.68 & 2.97 & 4.88 & & \\
\hline \multirow[t]{4}{*}{ BOD mg/L } & Spring & 450 & 321 & 241 & 160 & & \\
\hline & Summer & 726 & 682 & 490 & 425 & & \\
\hline & Autumn & 979 & 806 & 579 & 397 & & \\
\hline & Winter & 435 & 209 & 183 & 150 & & \\
\hline \multirow[t]{4}{*}{$\mathrm{COD} \mathrm{mg} / \mathrm{L}$} & Spring & 650 & 510 & 301.2 & 250 & & \\
\hline & Summer & 1204 & 948 & 628 & 503 & & \\
\hline & Autumn & 1016 & 957 & 686 & 420 & & \\
\hline & Winter & 571.1 & 301.1 & 280.1 & 230 & & \\
\hline \multirow[t]{4}{*}{ Turbidity } & Spring & 140 & 80.6 & 39.7 & 20.5 & & \\
\hline & Summer & 75.8 & 41.4 & 26.2 & 17.8 & & \\
\hline & Autumn & 96.2 & 37.1 & 18.8 & 9.5 & & \\
\hline & Winter & 197 & 82.2 & 67.7 & 12.4 & & \\
\hline
\end{tabular}

The symbols EC, TDS, S.S, DO, BOD and COD, A, B, C and D represent the electric conductivity, T total dissolved

solid, suspended solid, dissolved oxygen, biological oxygen demand and chemical oxygen demand Influent sewage water, aerated lagoon, facultative lagoon and effluent water, respectively. 
Table 3: Seasonal variations concentrations $(\mathrm{mg} / \mathrm{L})$ of some chemical parameters at the domestic sewage treatment plant during 2003-2004

\begin{tabular}{|l|l|c|c|c|c|}
\hline parameters & Seasons & A & B & C & D \\
\hline ammonia & Spring & 3.3 & 7.02 & 0.82 & 1.2 \\
\hline mg/L & Summer & 12.5 & 7.3 & 0.85 & 0.5 \\
\hline & Autumn & 8.5 & 6.9 & 3 & 0.3 \\
\hline & Winter & 6 & 5.2 & 2.3 & 0.3 \\
\hline sulphide & Spring & 0.6 & 0.92 & 3 & 0.18 \\
\hline mg/L & Summer & 3.64 & 0.33 & 3.3 & 3.26 \\
\hline & Autumn & 1.98 & 3.4 & 0.23 & 0.12 \\
\hline & Winter & 2.3 & 3.95 & 0.9 & 0.15 \\
\hline Chloride & Spring & 752 & 742 & 725 & 704 \\
\hline mg/L & Summer & 726 & 693 & 679 & 658 \\
\hline & Autumn & 783 & 775 & 729 & 712 \\
\hline & Winter & 1121 & 1120 & 1005 & 989.2 \\
\hline phosphate & Spring & 2.1 & 2 & 1.82 & 2.1 \\
\hline mg/L & Summer & 3.9 & 2.35 & 1.91 & 1.23 \\
\hline & Autumn & 4.61 & 1.32 & 1.85 & 1.3 \\
\hline & Winter & 3.02 & 1.55 & 1.07 & 1.55 \\
\hline Total & Spring & 5.42 & 2.35 & 4.9 & 4.85 \\
\hline phosphate & Summer & 7.06 & 6.37 & 4.92 & 3.15 \\
\hline mg/L & Autumn & 6.55 & 5.41 & 6.05 & 1.93 \\
\hline & Winter & 4.68 & 4.52 & 2.94 & 2.91 \\
\hline A,B, C, D are & res & & \\
\hline
\end{tabular}

A, B, C, D are represent Influent sewage water, aerated lagoon, facultative lagoon and effluent water, respectively.

\section{References}

1. U.S. Environmental Protection Agency (EPA), On-site Wastewater Treatment Systems Manual, Office of Water publication EPA/625/R-00/008. February (2002).

2. G. T. CHOBANOGLOUS, F. L. BURTON AND H. D. STENSEL, Wastewater Engineering (Treatment Disposal Reuse) / Metcalf \& Eddy, Inc., 4th Edition, McGrawHill Book Company(2003).

3. World Bank Supports China's Wastewater Treatment, The People’s Daily, Friday. November 30 ( 2001), Beijing . 
4. M. TAJRISHY AND A. ABRISHAMCHI, Integrated Approach to Water and Wastewater Management for Tehran, Iran, Water Conservation, Reuse, and Recycling: Proceedings of the Iranian-American Workshop, National Academies Press (2005).

5. L. A. MOHAMED. AND A.EL-MARADNY, Studies on the water quality of Abu Qir Bay during December 1999 to November 2000.The second international conference and exhibition for life and environment.3-5.April(2001) 361-383.

6. M.S.MASOUD, T. H. MAHMOUD AND A. M. ABDEL-HALIM, Chemical studies of El max Bay, Alex.The second international conference and exhibition for life and environment.3-5.April (2001) 339-360.

7. E.GONZALEZ, A. ELOSEGUIT AND J.POZO, Changes in the physico chemical characteristics of the Aguera stream water associated with human settlements. Vern. Internationl. Verein. Limnol.25( 1994) 1732-1737.

8. Annual Report of Environmental data from coastal Areas of the Gulf of Suez ,Red Sea proper and Gulf of Aqaba (Water monitoring Program CWMP)(1999).

9. C.R.GOLDAMAN, A.J.HORNE, Liminology.Edn.Mc Graw Hilly(1983).

10. Standard methods for examination of water and wastewater Analysis, Alpha, AWWA and WPCF17 $7^{\text {th }}$ edn,Washington DC (1995).

11. R. A. HORNA, Marine Chemistry .London, New York (1972).

12. J. P. BAKER,M.W.MILKE AND J. R. MIHELCIC, Relationship between Chemical Oxygen Demand and Theoretical Oxygen Demand for specific classes of organic chemicals. Wat. Res. 33(2 (1993) 27-334.

13. FAO., Wastewater treatment and use in agriculture, irigation and drainage. Paper no. 47. Rome.Italy. (1992).

14. M. J. HAMMER, Water and Wastewater. Ed, Prentice Hall, Inc. Asimon \& Schuster Company (1996). 